\title{
Regenerative tourism needs diverse economic practices
}

Associate Professor Jenny Cave ${ }^{a}$ and Professor Dianne Dredge ${ }^{b}$

a. Department of Business, School of Management, Swansea University, Wales, United Kingdom

b. The Tourism CoLab, Australia

May 2020, for TOURISM GEOGRAPHIES

\section{ABSTRACT}

Calls for a new relationship between tourism and capitalism have intensified as a result of COVID-19. The pandemic has exposed massive vulnerabilities in the tourism operating system, the effects of which have fallen unevenly across different groups and subsectors of tourism. Critics have been quick to point out capitalism's emphasis on resource exploitation, growth and profit is to blame and that tourism destinations have never been encouraged to foster diverse economic practices that would enhance resilient communities and regenerative tourism. The diverse economies framework envisages the co-existence of capitalist, alternative capitalist and non-capitalist practices and provides a pathway to more resilient and regenerative tourism practices in tourism. Tourism industry cases are used to illustrate the innovation inherent in diverse economic practices (enterprise, exchange, labour, transactions, property etc.) and illustrate their natural resilience as a result. Post COVID-19, a regenerative tourism that incorporates diverse economic practices will guide tourism practices worldwide to withstand future exigencies.

\section{KEYWORDS Tourism operating system; diverse economies; regenerative tourism; COVID-19}

\section{Beyond business as usual}

Who could have imagined how quickly tourism would come to such a grinding halt? COVID-19 measures including travel bans, border-crossing restrictions, lockdowns and physical distancing have created an inflexion, or a pivot point for social, economic and political life-and for the ecological wellbeing of the planet. In tourism, aviation, accommodation, travel companies and booking agents, attractions, retail, food and beverage outlets have been hit unevenly; supply chains have been severely disrupted; entire workforces have been stood down; and some businesses have managed to pivot to address emerging opportunities. At the time of writing, the Chinese economy is reportedly entering a revival stage. However, the ripple effects across Europe and the Americas are contributing to a perfect storm of public health concerns, unemployment and economic uncertainty. As the virus emerges on the African continent, a second wave looms large with the effects expected to reverberate for years to come.

Against this background, there have been growing calls for a new relationship with capitalism and new measures of success in tourism. Rising concerns about climate change, over-tourism, declining employment and labour conditions and resource degradation have all highlighted the inadequacy of the current capitalist 
system in addressing the failures of mass tourism. Now, under COVID-19, there are calls for tourism to move beyond 'business as usual' and to find a pathway to regenerative tourism. The question of how to move beyond simply advocating a shift to articulating what that shift might look like in tourism has received little attention, yet prototypes and experiments are everywhere. Tourism researchers have tended to take these examples as anomalies, as unlinked case studies, and there have been few attempts to draw systematic insights informing how the tourism operating system might be recast. The special issue on Diverse Economies in Tourism Planning and Development (2018, Issue 5) addressed this gap by seeking to develop a more coordinated set of insights into the diverse economies of tourism and to provide a pathway to recasting tourism systems.

\section{Towards a new operating system}

Over 25 years ago, Gibson-Graham, (1996) saw a need for post-capitalist economic alternatives given the exploitative nature of capitalism and the need for social and environmental systems to regenerate, if they are to become sustainable. Gibson- Graham conceptualised alternative and hybrid social worlds where capital accumulation, growth and profit were not the only motivations for economic organisation. They envisaged diverse social and community-based relationships where diverse kinds of monetary and non-monetary transactions took place and diverse kinds of value (e.g. community value, social good, regenerating natural resources, etc.) were produced (Gibson-Graham, 2006).

Initially, the alternative economies narrative encountered resistance from mainstream economic interests. 'Alternative' was perceived as oppositional to mainstream capitalism, which the authors had not intended, and this stymied widespread engagement with their ideas. However, over the years, new renderings of different kinds of economic exchange (e.g. the rise of collaborative and sharing economies) and alternative motivations for economic transactions (e.g. blended value, impact investing and the commons economy) have emerged. Gibson-Graham's ideas about diverse economies have proven to be a timeless inspiration for those seeking to examine the value and possibilities of alternative economic systems. Diversifying our economic practices can contribute to the uptake of regenerative practices and resilience.

In tourism, the dominant form of economic organisation - what we call the tourism operating system (TOS) has followed a capitalist agenda, with an emphasis on growth and profit. The value produced from the TOS is almost always measured in dollar terms (e.g. expenditure or investment) but the non-monetary value produced, co-created and shared in tourism is less well understood and rarely measured. While we know that travel and tourism produce benefits beyond money, the alternative economies literature has been little explored and thinking about diverse economies of tourism remains underdeveloped (see Mosedale 2012 as an exception). The occurrence of COVID-19 and calls for new forms of tourism have exposed the deficit in thinking and the need for new imaginaries about the TOS and diverse economies.

The need to re-imagine economic organisation has resurfaced more recently in the contributions of 
sustainability scientists (e.g. Rockstrom et. al., 2009) and economists (e.g. Raworth), feeding calls for regenerative economic operating systems. Critical issues in the current model of capitalism have been laid bare. Firstly, the accumulation of wealth in the top one percent, reduced labour rights and working conditions, a rise in casualisation of labour, a decline in the influence of organised labour, and a rise of the precariat class have created high levels of social and economic vulnerability among upper-middle, middle and lower working classes. Secondly, an emphasis on hyper-consumption as a driver of growth has led to exploitation of natural resources, a decline in the capacity of natural systems to regenerate, and impacts that have placed at risk the sustainability of natural systems. Raworth (2017) has argued that sustainable and regenerative economies require a decoupling of resource use from economic growth. The challenge in tourism, however, is that seven decades of growth have thwarted any appetite to imagine new and alternative economic models in tourism.

Now, COVID-19 has created an inflection point and post-covid predictions are already starting to emerge. Yet we see little evidence of concern for the detail of new tourism operating other than modified 'business as usual'. Predictions and claims must be read with caution. No one is an expert. There is no precedent and no robust foresight work to inform how to move forward. We can make educated predictions that international travel will take years to re-emerge; domestic, particularly local visitor economies, will be first to gain traction; and that major restructuring of aviation will increase cost, in turn affecting international travel. Beyond that, those who offer pre- dictions write through the lens of hope: 'bounce back'; a 'new world order'; or hope that we have time to learn and choose the optimal pathway forward. Our work in diverse economies contributes to this later stream of writing and responds to the need to rethink the values underpinning tourism operating systems. In particular, the need to acknowledge the importance of moving beyond the economic determinism of growth and profit and measures of success that emphasise volume or consumption.

\section{Alternative and diverse economies}

Anticipating the need for post-capitalist alternatives, given the failure of capitalism to address sustainable development and the tendency to exceed our social and environmental limits Gibson-Graham, (2008) spent many years exploring economic identity and dynamics. Their work conceptualises social worlds in which capitalism is not the only model. They envisage diverse economies - broadly conceived as systems of coordinated exchange through which value is produced, consumed and accumulated - organised into types of economic practice (conceived as enterprise, labour, property in 2006, then transactions and finance were added). Each of these five practices can be divided into capitalist, alternative capitalist and non-capitalist modes. Table 1 captures Gibson-Graham's seminal thinking. 
Table 1. An alternative economies framework

\begin{tabular}{|c|c|c|c|c|}
\hline ENTERPRISE & LABOUR & Property & TRANSACtions & FINANCE \\
\hline CAPITALIST & WAGE & Private & MARKET & MAINSTREAM FINANCE \\
\hline $\begin{array}{l}\text { Private firm. } \\
\text { Public company. } \\
\text { Multinational }\end{array}$ & $\begin{array}{l}\text { Salaried } \\
\text { Unionised } \\
\text { Part-time. } \\
\text { Casual }\end{array}$ & $\begin{array}{l}\text { Individually owned. } \\
\text { Collective. }\end{array}$ & $\begin{array}{c}\text { Free } \\
\text { Naturally protected. } \\
\text { Artificially protected. } \\
\text { Monopolised } \\
\text { Regulated } \\
\text { Niche }\end{array}$ & $\begin{array}{c}\text { Private banks } \\
\text { Insurance firms. } \\
\text { Financial services. } \\
\text { Derivatives }\end{array}$ \\
\hline ALTERNATIVE-CAPITALIST & Alternative Paid & Alternative Private & Alternative Market & ALteRnATIVE FinANCE \\
\hline $\begin{array}{c}\text { State-owned } \\
\text { enterprise. } \\
\text { Social enterprise. } \\
\text { B-Corp. }\end{array}$ & $\begin{array}{l}\text { Self-employed. } \\
\text { Cooperative. } \\
\text { Indentured. } \\
\text { Reciprocal labour. } \\
\text { In-kind. } \\
\text { Work for } \\
\text { welfare/other } \\
\text { benefits. }\end{array}$ & $\begin{array}{l}\text { State-owned. } \\
\text { Customary (clan) } \\
\text { land. } \\
\text { Community land } \\
\text { Trusts. } \\
\text { Indigenous } \\
\text { Knowledge (IP). }\end{array}$ & $\begin{array}{l}\text { Sale of public goods. } \\
\text { Ethical 'fair-trade'. } \\
\text { Local trading systems. } \\
\text { Alternative currencies. } \\
\text { Underground market. } \\
\text { Co-operatives. } \\
\text { Barter, swap. } \\
\text { Informal market. }\end{array}$ & $\begin{array}{l}\text { Cooperative banks. } \\
\text { Credit unions. } \\
\text { Community-based } \\
\text { lenders. } \\
\text { Micro-finance. } \\
\text { Impact investing. }\end{array}$ \\
\hline NON-CAPITALIST & UNPAID & OPEN ACCESS & $\begin{array}{l}\text { NON-MARKET } \\
\text { TRANSACTIONS }\end{array}$ & NON-MARKET FINANCE \\
\hline $\begin{array}{l}\text { Communal } \\
\text { Independent } \\
\text { Feudal } \\
\text { Slave }\end{array}$ & $\begin{array}{c}\text { Housework } \\
\text { Family care. } \\
\text { Neighbourhood } \\
\text { work. } \\
\text { Volunteer. } \\
\text { Self-provisioning } \\
\text { labour. } \\
\text { Slave labour. }\end{array}$ & $\begin{array}{c}\text { Atmosphere. } \\
\text { International } \\
\text { waters. } \\
\text { Open source IP. } \\
\text { Outer space. }\end{array}$ & $\begin{array}{c}\text { Household flows. } \\
\text { Gifting } \\
\text { Indigenous exchange. } \\
\text { State allocations. } \\
\text { State appropriations. } \\
\text { Gleaning. } \\
\text { Hunt, fish, and gather. } \\
\text { Theft, poaching, } \\
\text { piracy. }\end{array}$ & $\begin{array}{c}\text { Sweat equity. } \\
\text { Family lending. } \\
\text { Donations } \\
\text { Interest-free loans. } \\
\text { Remittances }\end{array}$ \\
\hline
\end{tabular}

After Gibson-Graham et al. (2013).

A key value of Gibson-Graham's framework is to highlight a range of economic practices that have been largely ignored by mainstream economic thinking. In placing these practices in a framework, they highlight the coexistence of different types of market, alternative market and non-capitalist practices that remain hidden in plain sight. In the context of tourism, this framework helps to recognise alternative and diverse economic practices that exist outside mainstream tourism operating systems and that are often obscured in frequent calls for "a new relationship with capitalism" (Fletcher, 2011).

\section{Diverse economies in tourism}

So, does the diverse economies framework, and in particular, the investigations under- taken as part of the 
Diverse Economies in Tourism special issue, offer any insights for tourism in the context of COVID-19? From our 2018 call and the industry case studies below, we find that the diverse economies framework helps to deconstruct economic practices in tourism. The individual papers comprising the Special Issue shone a light on different economic practices in tourism, such as the nature of labour (e.g. paid, unpaid and alternative); types of transactions (e.g. monetary, sharing, gifting, favours, etc); and the types and sources of finance (impact investing, blended value). Such insights into the nature of tourism enterprise helped to highlight the different ways that responsibility was construed by public, private and other types of actor. Importantly, the special issue also helped to highlight the various ways that value was (co)created in both monetary and non-monetary forms. Put simply, by deconstructing these diverse economies of tourism, we see an opportunity to articulate and measure the diversity of tourism and visitor economies in more systematic and meaningful ways. This in turn would help move beyond simply advocating for a new relationship to capitalism, by acknowledging the presence and contribution of existing alternative economic practices.

The special issue also revealed that, in tourism, alternative economic practices were well established in the Global South and in indigenous communities in particular. The Global South, distanced by geography and attitudes from the largely industrial North, enacts alternative economic models with ease and has a long tradition of locally constituted enterprises that adapt to opportunities of global interaction but in the main are not dependent upon them. The growth of mass tourism sourced from bourgeoning middle classes (e.g. China and India) has exposed many destinations to the overreliance on narrow international markets. However, cultural resilience, alertness to change, capacity to adapt grounded social values, collective notions of valuecreation, and alternative economic transactions (e.g. sharing and gifting) are demonstrated by case studies contained in the Diverse Economies volume (Cave \& Dredge, 2018; 2020). Situational and cultural antecedents, new interpretations of opportunity, and the alternative values underpinning exchange reveal in these cases, how enterprises operate outside the 'profit and growth economy' and 'business as usual' norms.

\section{Lessons: Diverse economic practices in tourism}

\section{Hybrid cultural/mainstream economy: Indigenous ecotourism, New Zealand (ALT-CAPITALIST):}

Wealth and 'well-th' are values that underpin the alternative economic ecotourism operation, Blue Penguins Pukekura. Collectively owned by a Maori community in Dunedin, Aotearoa-New Zealand, the collective operates a hybrid Alt-Capitalist and Non-Capitalist enterprise. The enterprise thrives within a market economy generally hostile to socio-ecological activities because it invests in capacity building, socio- cultural collaboration and stable relationships that bridge both mainstream 'European' and Indigenous worldviews. The organisation values both unpaid and paid labour within cultural mores at strategic, operational and governance decision-making levels, yet also functions within mainstream regulatory and taxation regimes. Labour allocations are made according to skill and to build capacity/succession. This regenerative enterprise mediates global (tourism markets) and local (Maori cultural) values and ideologies to create fiscal wealth as well as 'well-th', defined as social, physical and mindful wellbeing within the social structure of the tribe. Most 
importantly, the suc- cessful initiative enables economic resilience against exogenous shock enhances cultural continuance and resistance to further social predation by colonization (Amoamo et al., 2018).

\section{Collaborative technology platforms: Danish walking trail (ALT-CAPITALIST)}

The collaborative technology platform model of a walking trail in Southern Denmark is an example of bottomup co-operative development within the alternative capitalist economy. It leverages pre-existing conditions, i.e. unused public land, a resourceful migrant community, volunteer labour, a heritage museum with a regional mandate, and an iconic island bio-scape. Two female leisure entrepreneurs conceived, initiated and developed a coastal walking trail, using digital platform technologies to enable access to the trail and direct connections with locals to book experiences (e.g. dinners, birdwatching, berry picking). The collaborative business model is community-driven but needed a core agency to host the platform. The regional non-profit museum saw an opportunity beyond material collections and walls to redefine its role, connect with their communities, undertake large-scale heritage landscape interpretation and valorise local resources for visitors. An additional benefit was to extend its own revenue potential and residents' wellbeing and connectedness. Ideologically, the organisation is communitarian since it co-opts a public partner, public resources, volunteers and is supported by private philanthropic funding for micro-entrepreneurs. Thus, benefits are localised and not extracted by a global company (Gyimothy \& Meged, 2018)

\section{Community value co-creation: Open monuments event, Sardinia (NON-CAPITALIST/ALT-}

\section{FINANCE)}

Collective co-creation of a cultural tourism event in Sardinia co-exists alongside dominant forms of capitalism. Imago Mundi, a not-for-profit organisation and member of Sardex, an alternative finance complementary currency community aimed at alleviating the impacts of the global financial crisis, initiated the Open Monuments event because of the need to generate employment in the severe economic downturn experienced by Sardinia. An experience that parallels the impact of COVID-19. Direct and indirect value cocreation is developed within the organisation and its broader network of sup- pliers and partners by generating social values such as trust, dialogue and reciprocity as collective benefits for the multiple actors involved. Actors, firms and customers adopt specific positions and roles within social structures, the strength of which depends on proximity of social ties. The event has become an annual festival, engaging over 50 local councils and local associations spread all over the island, attracting around 17,000 volunteers, and 300,000 yearly visitors, enabled largely by volunteer labour and public funds. Stakeholders thus co-create noncapitalist forms of place-based and community value, as well as develop social capital and local resilience through relational, networking activity and collaborative practices in cultural, economic and environmental domains (Cannas, 2018).

\section{Local associations, family networks: Ecuadorian beaches (NON-CAPITALIST)}

The informal sector in Latin America has a long tradition of solidarity. Tourism development in four fishing communities located on beaches attractive to tourists' shows that economic behaviours can leverage 
alternative value producing opportunities linked to family survival and solidarity. However, they are affected by the micro-politics of local community networks and a disconnect with modern regulatory frameworks. Unincorporated associations, unregistered tourism establishments, and small and medium enterprises thrive here outside public tax and social health systems as self- employed entrepreneurs and family tourism enterprises. Typically, the males of the family dedicated their work to fishing and the women lead tourismrelated activities that complement the family budget and call in an informal workforce of close relatives and family members. Here, capitalistic tourism enterprise is the exception not the norm.

However, the Ecuadorian State supports a capitalist form of 'doing business', enacted through legal and regulatory practices of professional registration, taxation, social security and industry association membership. Yet in reality, less than one third of Ecuadorian enterprises fulfil these legal requirements and are industry or tax registered, hold professional licenses or comply with the social security system. Most of these enterprises are affiliated to local industry associations, which are active in community development, such as improving physical infrastructure, and environmental care (e.g. beach cleaning). Further, they redistribute economic surpluses, seek social compromise and community unity to act as a genuine and alternative source of tourism planning and regulation but also actively resist the Ecuadorian state and local administrations. Such resistance creates a diverse range of non- and alt-capitalist forms that operate alongside each other, all serving the tourist market but operating outside officialdom in ways that enhance resilience but produce precarity in employment, equity and wage security (Pecot et al., 2018).

\section{Alternative development: Corporate hotels and community priorities, Fiji (ALT-CAPITALIST, ALT-}

\section{MARKET)}

Modernity is not a worldwide norm. International agencies from the developed, industrial North usually frame development aid for small island states to address vulnerability and the need for 'new' skills. In the process, this inadvertently deprioritises local issues, systems and cultural knowledge. Such aid is often short-term, periodic and project focused, leading to discontinuity, increased vulnerability and overreliance on out- side, short-term provision projects and equipment. In Fiji, despite encouragement by government for foreign investment in the resort sector, international hotels cannot own land, but lease it from the tribal landholder. Further, hotels and tourism operations are required to contribute to community development by preferential employment of local indigenous Fijians; fees for village tours and beach access, as well as scholarships and leasehold fees. However, the majority of corporate hotels rationalise the local leasehold agreements and 'sustainability' initiatives (reef remediation, beach cleaning) as specific community benefits and corporate social responsibility (CSR) initiatives that enhance their global brand standards. With some exceptions, hotels rarely consider communities as equal partners in development of goals or understand the socio-cultural realities of Fijian collective priorities, nor the direct linkage of hotels with village life. Indigenous values and belief systems privilege shared resources and communal land-ownership so that income from external sources such as leases, wages from employment in hotels, performance fees and handicrafts is pooled within the village to develop communal infrastructure or for community development, although high cost equipment 
might be purchased by an individual for their enterprise.

The Development First framework proposed in this case example, is an effective mechanism to achieve meaningful outcomes for both communities and hotels. The framework responds to local human development needs (e.g. schools, health care) as well as to funding partner goals. Recognition in the framework of existing culturally- based alternative market economies keeps the well-being of the wider community to the fore by strengthening bottom-up processes that align labour with ethics of self- reliance and obligation. Such reciprocity and awareness of customary exchange connects the tourism sector to the livelihood practices of ordinary people, as well as to indigenous philosophies and local interpretations of development (Hughes \& Scheyvens, 2018).

Collaborative commons, moral incentives: Post-Castro Cuba (NON-CAPITALIST, ALT-PAID, ALTMARKET)

Post-Castro reforms, introduced to open up trade with the United States have enabled economic alternatives to develop that both preserve the central heritage and values of local Cuban culture and respond to global forces of tourism. In this case, the analogy of pre-1962 American oldsmobile (an iconic image associated with Cuba) is used to unpack the idea that the original vehicle exterior can be preserved while contemporary locally inspired interior adaptions are made for comfort and functionality. The everyday practices of tourism in Cuba are an example of adaptive resourcefulness in the face of social and ideological adaptation to economic conditions and limited investment. Cubans operate tourism within a system that is both highly regulated (i.e. formal socialist economy) but also involves significant levels of informality (i.e. informal economy) illustrating economic transactions that combine both monetary and non- monetary models of development and that balance livelihood and well-being.

The industry is tightly regulated through the ministries of Tourism, Labour and the Armed Forces resulting in close surveillance, which ironically limits development and extracts profits from tourism entrepreneurs. However, Cubans use social mechanisms to subvert the formal regulatory process. For example, they expand capacity through a collaborative commons economy where individual benefit it is not the aim. New selfemployment opportunities enable entrepreneurs to open private operations (restaurants, casas particulares or rooms for rent). These operate in a horizontal and collaborative schema that integrates entrepreneurial collaboration, reciprocal exchange, and the State's requirements. Transactions occur as verbal agreements, referrals to trusted friends/family to expand capacity, loans of scarce equipment or as refusals of service if someone proves untrustworthy, as well as social rather than formal contracts of employment. Residents prioritise the needs and livelihoods of others and subsume their own. Hence, in this case, political and economic forms of exchange are interwoven with the socialist ideology that are communal and relational, producing alternative forms of enterprises, types of transactions, and forms of labour not seen elsewhere in the industry (Balslev Clausen \& Velazquez Garcia, 2018). 


\section{Diverse economy perspective: Air New Zealand (CAPITALIST)}

Alterative economies are often argued as local in scale, but major companies, such as airlines, can co-create diverse models of exchange by activating different stakeholder interests, even when globally regulated and focused on market capitalisation. In the case of airlines, in aircraft design, flight trajectories, fuels, etc. Air New Zealand is a capitalist model that nonetheless grounds its business and operations on socio-cultural dimensions related to its bi-cultural national context. Indigenous Maori have been the flag-bearers and face of the country's tourism industry since 1895 , although many argue this as cultural appropriation. Suppliers to the airline at all levels: from governance to maintenance, operations and inventory as well as marketing, must demonstrate compliance with ethical procurement and the airline's business practices. The airline emphasizes social capital development through a sustained deep commitment to women in leadership and female pilots, to cultural symbolism and materials, and to working with social enterprises and vulnerable communities (Tham \& Evers-Swindell, 2018).

\section{Discussion and conclusions}

In sum, we return to the question of whether the diverse economies framework offers any useful insights and lessons for moving forward in a post-COVID-19 world. While a razor-sharp focus on dealing with the immediate public health challenges is essential, as the pandemic peaks, infection rates flatten and then rebound, questions are starting to emerge about how and when to restart local, regional and national economies. Three paths open up before us: hope of a 'bounce back'; hope to enter a new world order; or hope that we have time to learn and choose the optimal pathway forward.

It is clear that COVID-19 has brought to the fore a range of failures in the traditional TOS and has highlighted widespread vulnerabilities from workers and small and medium-sized enterprises to multi-national corporations and global tourism supply chains. Tourism researchers have often hurled rocks from the sidelines, calling for 'a new relationship with capitalism' or claiming 'tourism is dead', but they have done little to explore, understand or contribute much needed alternative renderings of the tourism operating system.

We believe the diverse economies framework provides a promising pathway forward by directing attention towards the diversity of economic practices of tourism. If we recognise that transformation of the tourism operating system is necessary in order to create more resilient and sustainable tourism and visitor economies, then surely nuanced renderings and systematic analyses of alternative and diverse tourism practices are a useful step forward. Such renderings of the different enterprises, types of labour, property, exchange and finance that make up the production of tourism goods, services and experiences are the first step in designing tourism economies for the future. The second step would be to value these diverse economic practices by instigating appropriate evaluation and measurement of alternative models and practices. The third step would be to develop policy support mechanisms that acknowledge and encourage diversified economic practices with the explicit intention to reduce the overreliance on the dominant capitalist practices. The present 
distinction between formal and informal economies is perhaps judgmental and unhelpful in imagining the potential contributions that diverse economies of tourism can play in building resilience, well-being and connectedness, while also reducing vulnerability.

\section{References}

Amoamo, M., Ruckstuhl, K., \& Ruwhiu, D. (2018). Balancing indigenous values through diverse economies: A case study of Maori Ecotourism. Tourism Planning \& Development, 15(5), 478-495. doi: $10.1080 / 21568316.2018 .1481452$

Balslev Clausen, H., \& Velazquez Garcia, M. A. (2018). The tourism model in Post-Castro Cuba: Tensions between ideology and economic realities. Tourism Planning \& Development, 15(5), 551-566. doi: $10.1080 / 21568316.2018 .1504817$

Cannas, R. (2018). Diverse economies of collective value co-creation: The open monuments event. Tourism Planning \& Development, 15(5), 535-550. doi: 10.1080/21568316.2018.1505651

Cave, J., \& Dredge, D. (2018). Reworking tourism: Diverse economies in a changing world. Tourism Planning \& Development, 15(5), 473-477. doi: 10.1080/21568316.2018.1510659

Cave, J., \& Dredge, D. Eds., (2020). Reworking tourism: Diverse economies in a changing world. Routledge.

Fletcher, R. (2011). Sustaining tourism, sustaining capitalism? The tourism industry's role in global capitalist expansion. Tourism Geographies, 13(3), 443-461. doi: 10.1080/14616688.2011. 570372

Gibson-Graham, J. K. (1996). The end of capitalism (as we knew it): a feminist critique of political economy. Blackwell.

Gibson-Graham, J. K. (2006). A postcapitalist politics. University of Minnesota Press.

Gibson-Graham, J. K. (2008). Diverse economies: performative practices for "other" worlds. Progress in Human Geography, 32(5), 613-632. doi: 10.1177/0309132508090821

Gibson-Graham, J. K., Cameron, J., \& Healy, S. (2013). Take back the economy: an ethical guide for transforming our communities. University of Minnesota Press.

Gyimothy, S., \& Meged, J. W. (2018). The Camøno: A communitarian walking trail in the sharing economy. Tourism Planning \& Development, 15(5), 496-515. doi: 10.1080/21568316.2018. 1504318

Healy, S. (2009). Alternative economies. In R. Kitchin, \& N. Thrift (Eds.), International encyclopaedia of human geography (pp. 338-344). Elsevier.

Hughes, E., \& Scheyvens, R. (2018). Development alternatives in the Pacific: How tourism corporates can work more effectively with local communities. Tourism Planning \& Development, 15(5), 516-534. doi: 10.1080/21568316.2018.1478881

Pecot, M., Gavilanes, J., \& De Viteri, A. S. (2018). Tales of informality: Tourism development in four Ecuadorian beaches. Tourism Planning \& Development, 15(5), 584-599. doi: 10.1080/ 21568316.2018.1504319

Rockstrom, J., Steffen, W., Noone, K., Persson, A., Chapin, F. S., Lambin, E. F., Lenton, T. M., Scheffer, M., Folke, C., Schellnhuber, H. J., Nykvist, B., de Wit, C. A., Hughes, T., van der Leeuw, S., Rodhe, H., Sorlin, S., Snyder, P. K., Costanza, R., Svedin, U., Foley, J. A. (2009). A safe operating space for 
humanity. Nature, 461(7263), 472-475. doi: 10.1038/461472a

Rowarth, K. (2017). Doughnut economics: Seven ways to think like a 21st-century economist. Chelsea Green Publishing.

Tham, A., \& Evers-Swindell, B. (2018). Stand up and be counted-A diverse economy perspective of air New Zealand. Tourism Planning \& Development, 15(5), 567-583. doi: 10.1080/21568316.2018.1504816 